Historic, archived document

Do not assume content reflects current scientific knowledge, policies, or practices. 
$A 280.39$

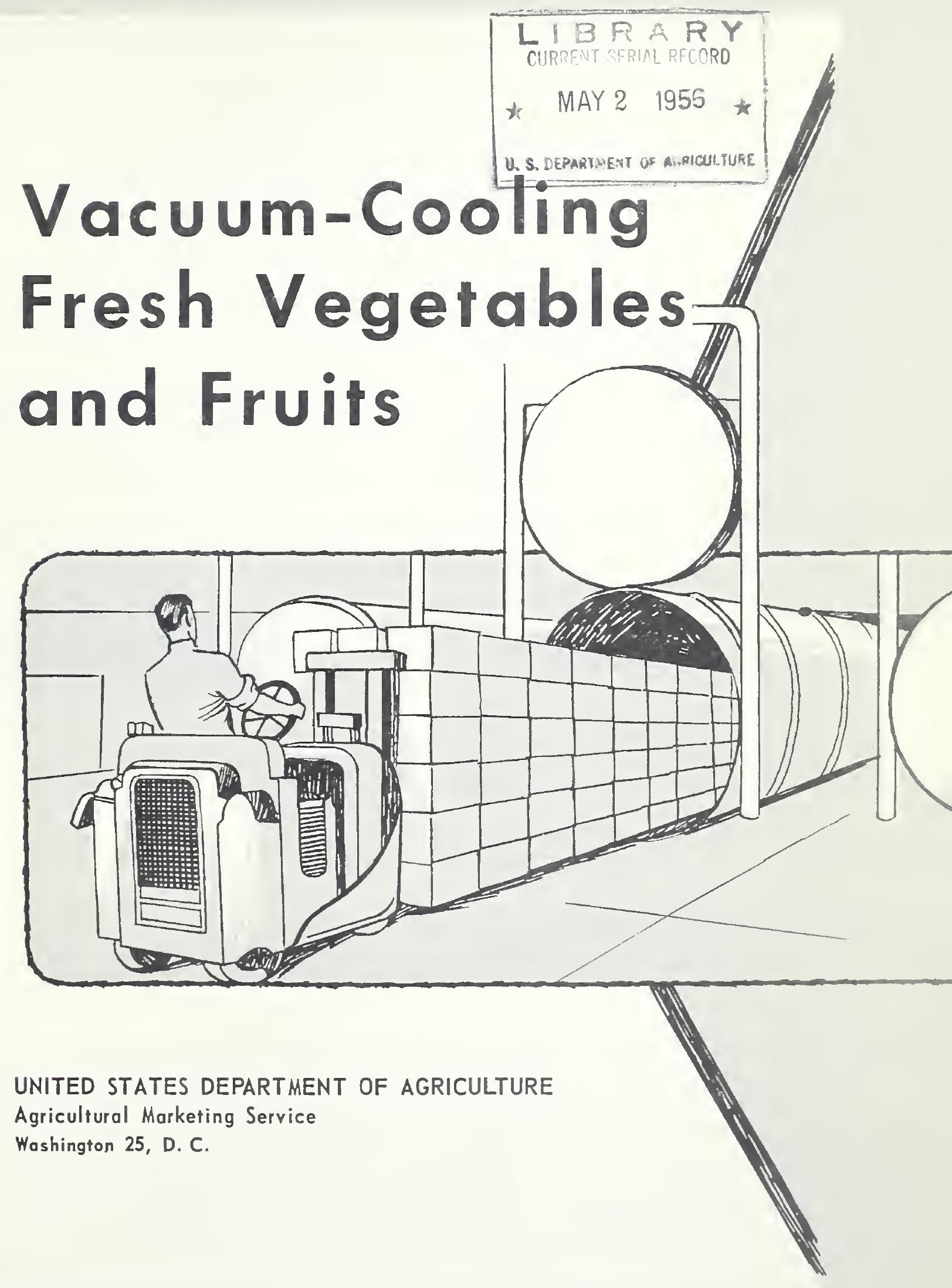



B. A. Friedman, senior plant pathologist, and

W. A. Radspinner, associate horticulturist

Biological üciences Brench

Agricultural Marketing Service

New York, N. Y.

Vacuum-cooling for agriculturat produce was used comnercially for the first time in 1948 when 34 carloads of lettuce were cooled by this method at Salinas, Calif. Since then development has been so rapid that it was estimated that about 40 to 85 percent of the lettuce crop of Caiffornia and Arizona were vacuum-cooled in 1954 (4, 14). I/ Vacuum-coolers for lettuce have been built in Texas, Wisconsin, and Canada. A similar installation for the precooling of prepackaged vegetables has been in use since 1950 in New Jersey (9).

The purpose of this report is to summarize results of tests on vacuumcooling of vegetables and fruits to date.

\section{PRINCIPLES OF VACUUM-COOLING}

Evaporative cooling was utilized early in the history of man to cool water as in earthenware jugs. Cooling towers and spray ponds are later applications of the same princ1ple. At normal atmospheric pressure (29.92 inches or $760 \mathrm{~mm}$. of mercury) water boils at $212^{\circ} \mathrm{F}$. As the pressure is reduced, however, the boiling point of water is reduced until at a partial pressure of 0.1.8 inches $\left(4.6 \mathrm{~mm}\right.$ ) of mercury, water boils at $32^{\circ}(15)$. The water which evaporates from fresh fmits and vegetables cools the commodity to a temperature corresponding to the evaporating temperature of vater'at the redused pressure or vacuum attained (ló).

In commercial practice, air is pumped out of the vacuum chamber either by a multi-stace steam ejector system-and barometric condenser, or by electrically driven mechanical pumps connected with refrigerated condensers (I8).

\section{TEMPERATURE CHANGES DURING VACUUM-COOLING}

Relation of Ratio of Surface to Volume of Produce. The results obtained by the vacuum-cooling of a number of fruits and vegetabies show that leafy vegetables, which have a large surface area for evaporgtion in proportion to their volume, are rapidly cooled (table 1). Commodities which have a somewhat smaller ratio of surface area to volume are generally less readily vacuum-cooled (table 2); fruits and vegetables. which have a small evaporating surface in proportion to their volume are usually poorly cooled by vacuum methods (table 3 ).

$1 /$ Underscored figures in parentheses refer to Luterature Cited, page 11. 
In additon to the sufaceovolume relaticnshipg there as eviderce that the rate of evaporaticn during racumsosoling is affected by the stmature, tissue density, thickness of sine, and waximess of the different fruits and vegetabies。

Vacuum-Cocing of Wet and Dry Produce. Inasmah as the temperature reduction during vacuum sooling is the result of evaporation of water. some fmuts and vegetables have been mistened with water to detemine whetrer Iower temperatures would residit. The wetting of celery. amarberries, grapes, and mushrooms had littie effest (table 4), whereas the wetting of strawberiles caused a substantial cooling ( $f$ ig. i).

In tests to determine the effects of added molsturs, ceieryg grapes, and strawberries were dry when removed from the vacuum chamber. Wet mushrooms felt slightly moister than dry mushrooms after vacuum-cosings and in addition developed a sifght browish discoloration. Friedman ( 7$)^{9}$ fourd that wet spinach remained wet after it had beer vacuumescoled for oriy 5 minutes.

Vacuum-cooling of strawberries, and possibly cther commodities, might be practicabie commerciaIIy if they were moist from rains heavy dews from being washed, or from application of fungioides in water. Vaculmacoiing might serve to dry moist commodities.

Weto and Dry-bulb Temperature Readings During Vacuum Cycie. Vacuumocooling of fresh fraits and vegetabies mist be controlled accurateiy to avcid the possibility of freezirg. Vacuum methods have been used comercially to freeze shelled greein peas ( 17 ). Wet-buib thermometers generaliy are used for controlling the vacuumocooling process. A dry-buib thermoneter alone would obviousiy be unsatisfactory to indicate commoity temperature. When lettuce temperatures were

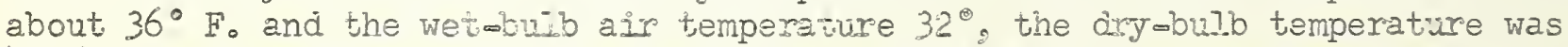
49.5\%. By mears of we ar ar dry-buib themoscupies, ajr temperature readings were taken during the vasummocoling of prepackaged regetables (fig。2)。 In the first part of the cyole, when pressure apparentiy was stiil high and the air was saturated with water vapor, we and dry-bulb temperstures were approximately the same. When the mian vacuum bocster valve was opened 5 3/2 mirutes after the start of the vacuum sycle, the pressure dropped rapidily and the temperature spread between the weto and dry-bulib readings increased until by I? minutes after the start of the cycle there was a difference $0 f^{\prime} 17: 12$ degrees。

Relation of Amount of Vacuum and Temperatire. It was noted previcusly that the temperature at which water bojls $\mathrm{s}$ detemined oy pressure. The Iower the pressure, the lower the boiling temperature. This principle was demonstrated experimentally by vacuum zooling spinach for 5 minutes at 2 dififerent pressures, namely at 5.0 and $4.5 \mathrm{~mm}$ of mercury. Tre pressures were measured by a MrLeod gage. At the start the temperature of the spinach was $80^{\circ} \mathrm{F}$. The temperature of the spinach vacuum-cooled at $5.0 \mathrm{~mm}$. was $39^{\circ}$, while that at $4.5 \mathrm{~mm}$. was $32^{\circ}$.

Effect of Initial Temperature on Cooling. To datermire what elfect the initial temperature has upon the rate ot cooling, warm ama cool loads cf celery and lettuse were vasuumacoled together. The resuits (fige. 3 ard 4 ) show that 
the initial temperature of lettuce has little effect upon its final temperature. Experiments with spinach (7) showed the same results in this respect. The initial temperature of celery, on the other hand, has a marked effect upon its final temperature, a difference of about 10 degrees. This is probably due to the smaller surface area-volume ratio of celery.

Many inquiries have been received regarding the possibility of vacuurn-cooling celery. This commodity is not readily vacuumecooled (table 2). However, possibly a double vacuum cycle, $i_{0} e_{2}$ twc successive vacuum-coclings may be used for celery (fig. 4). If a double vacuum cycie is employed, observations should be made to see whether there is excessive shriveling。 Other possible methods would be to lengthen the time under vacuum (9), to wet the celery prior to vacuum-cooling, or to use a greater vacuum (7). In the last method, however, the possibility of freezing, especially of the leaves, would have to be considered.

Relation of Type of Container to Rate of Precooling. Leafy vegetables which were packaged in cellophane bags, packed in cartons, and stacked solidily on pallets, were rapidly vacuum-cooled, whereas similarly handled commodities were cooled very slowly by means of conventional cooling in cold air (2).

In another experiment, lettuce was vacuum-cooled in fiberboard containers and in unlined, wooden, wirebound crates at the same time to determine the effect of type of container upon the rate of cooling. The results (fig. 5) give further evidence that a commodity which can be vacuumocooled rapidly can be packed in any type of container without affecting significantly the rate of cooling if there are some openings to permit the escape ô air and water vapor.

\section{WEIGHT LOSS DURING VACUUM $\infty$ COOLING}

It has been supposed by some that considerable water is lost by evaporation during vacuum ccoling. It has been calcuiated that to cooI 100 pounds of coleslaw from $70^{\circ} \mathrm{F}$. to $35^{\circ}$ it is necessary to extract approximately 2,325 B.t.t. This would require the evaporation of about 2.2 pounds of water or about 2.2 percent of the weight. In actual practice, the weight loss of coleslaw during vacuum-cooling was about 2.0 percent (9). The weight losses of several cormodities during vacuumcooling are shown (tabie 5)。

\section{EFFECT OF VACUTM-COOLING ON QUALITY OF PRODUCE}

Weight losses during vacuum-cooling are small, and shriveiing or wilting in vegetables has not been a problem in commercial vacuum-cooling.

Brown spot of Iettuce which is troublesome at times has been attributed to suffocation during vacuum-cooling (II). However, brown spot also occurs in lettuce which has not been vacuum-cjoled. Further, some lettuce has been 
vacuumcooled for 8 hours and then stored for 3 weeks at $38^{\circ}$ F. without any evidence of suffocation or brom spotal

Appies, potatoes, and tomatoes have suffered some injury during vacuum cooling (6, 8), but no serious consideration has been given to cooling them by this process. Aside from these comodities, no impaniment of either flavor or quality has been obserred in other vacuumaoled fruits and vegetables.

Trade publications have stated that the vacuun process destrojs bacteria Which cause decay in Iettuce. No evidence has been seen to substantiate this statement. The res:stance of bacterial cells to adverse conditions is well know and it is probable that if the recum were io mpture bacteria, it would also injure the regetabie cells. In factg a common nethod of preserving bacteria is to freezerdry them under extrenely high vacuum.

Inhibition of decay by vacuum-cooling is probably a result of thorough precooling plus drying the surfaces of produce. Low temperature is the principal inhibitor of decay. In a comparison of dry-packed, vacuum-cooled lettuce and icempacked, non-vacuur-cooled lettuce, littie difference was found in the amount of waste under strictity controlled conditicns (I2).

\section{SONE ECONONIC CONSIDERATIONS OF VACUUTMCOOIING}

According to trade reports the initial investment for vacuum equipment is high, and apparerity operation over long seasons is necessary to justify the costs involved. The lates: development has been the construction of vacuum chambers large enough to accommodate a loaded refrigerator railroad car or truck trailer (13).

Vacuum-cooling has created a revolutionary change in the handling of lettuce. The process pemits the use of any type of container for packaging. Lettuce can be packed in the fieldg elsminating the reed for a packing house. It is no longer necessary to use packaged ice or to topoice the lettuce in transit, ard space is thus better utilized. Burikhat (2) has estimated that Iettuce paking and shipping costs heve been reouced 25 percent sirce the advent of racuumocooling.

It can be anticipated that if rew lange acreages are pianted to lettuce, vacuum=cooling plants will be consimoted. Also, there wili piobably be further refinements in vacuumocosiling of lettuce and its use extended to prepackaged lettroe.

Spinach, culeslaw, and rixed sa?ad can be hydrocooled (flooded or immersed in ice water) pricr to packaging, but by the time they are spun-dried and

2/ Unpublished data by G. L. Rygg and D。H. Dewey. 
packaged an appreciable amount of refrigeration is lost. Vacuum-cooling permits cooling after the produce is bagged and packed in master containers. Vacuumcooling has made possible the marketing of spinach, coleslaw, and mired salad during hot weather when it previously was not economical because of decay。

Another advantage of the vacuum-cooling process is the rapidity with which commodities can be precooled. Indeed, the method is very frequently called "flash" cooling. Commercially, lettuce is precooled in about 30 minutes: prepackaged leafy vegetables are precooled in about 15 minutes。

The results to date indicate that vacuum-ccoling may be suitable for several items not commercially precooled, such as strawberries, mushrooms, sweet corm, and possibly celery.

Injections of fungicidal gases and mixtures of carbon dioxide and oxygen during the vacuum process to lengthen shelf-life and inhibit decay may have possibilities but await future tests. 
Table I, Exfectiveness of vacuumcooling vegetables with large surface area-to-volume ratio

\begin{tabular}{|c|c|c|c|c|}
\hline Comnodity & Contaziner & $\begin{array}{l}\text { Duration } \\
\text { of } \\
\text { vaclium } \\
\text { cycie }\end{array}$ & $\begin{array}{l}\text { Temperatur } \\
\text { Beginning } \\
\text { of cycle }\end{array}$ & $\begin{array}{l}\text { modity at - } \\
\text { End of } \\
\text { cycle }\end{array}$ \\
\hline & & Minutes & ${ }^{\circ}$ & F. \\
\hline $\begin{array}{l}\text { Brussel sprouts } \\
\text { Cabbage } \\
\text { Coleslat } \\
\text { Coleslaw } \\
\text { Endive } \\
\text { Endive, Belgian } \\
\text { Escarole } \\
\text { Lettuce 2// } \\
\text { Lettuce } 3 / \\
\text { Lettuce } \\
\text { Lettuce } \\
\text { Lettuce } \\
\text { Parsley } \\
\text { Salad mix } 3 / \\
\text { Soup mix } 3 / \\
\text { Spinach } \\
\text { Spinach 3/ } \\
\text { Spinach }\end{array}$ & $\begin{array}{l}\text { Quart cup } \\
\text { Nore } \\
\text { Cellophane bag } \\
\text { Cellophane bag } \\
\text { Crate } \\
\text { Bundle } \\
\text { Grate } \\
\text { Crate } \\
\text { Crate } \\
\text { Cellophane wrap } \\
\text { Carton } \\
\text { Carton } \\
\text { Crate } \\
\text { Cellophane ba.g } \\
\text { Cellophane bas } \\
\text { Cellophane bag } \\
\text { Cellophane bag } \\
\text { Bushel basket }\end{array}$ & $\begin{array}{l}20 \\
20 \\
20 \\
18 \\
20 \\
14 \\
20 \\
55 \\
20 \\
10 \\
13 \\
13 \\
20 \\
20 \\
20 \\
20 \\
20 \\
10\end{array}$ & $\begin{array}{l}68 \\
68 \\
67 \\
65 \\
68 \\
67 \\
68 \\
60-70 \\
72 \\
75 \\
71 \\
69 \\
68 \\
65 \\
62 \\
65 \\
66 \\
67\end{array}$ & $\begin{array}{l}38 \\
40 \\
34 \\
32-36 \\
36 \\
40 \\
36 \\
32-33 \\
32 \\
34 \\
36 \\
34 \\
34 \\
35 \\
34 \\
34 \\
35 \\
37\end{array}$ \\
\hline
\end{tabular}

If Results were obtained by Fräedman (1, 8, 2, 10), and from unpublished data unless otherwise indicated.

2/ Data from Clements (3).

3/ Data from Barger (I)。 
Table 2. meffectiveness of vacuum-cooling vegetables with medium surface area-to-volume ratio

\begin{tabular}{|c|c|c|c|c|}
\hline Commodity $^{\text {I/ }}$ & Container & $\begin{array}{l}\text { Duration } \\
\text { of } \\
\text { vacuum } \\
\text { cycle }\end{array}$ & $\begin{array}{l}\text { Temperature } \\
\text { Beginning } \\
\text { of cycle }\end{array}$ & $\frac{\text { of commodity ato }}{\begin{array}{l}\text { End of } \\
\text { cycle }\end{array}}$ \\
\hline & & Minutes & $\underline{F}_{0}$ & ${ }^{0} \bar{F}_{0}$ \\
\hline $\begin{array}{l}\text { Artichoke } \\
\text { Asparagus 2/ } \\
\text { Beans, snap } \\
\text { Beans, snap } \\
\text { Beans, snap } \\
\text { Broccoli } \\
\text { Broccoli } \\
\text { Cauliflower } \\
\text { Cauiiflower } \\
\text { Celery } \\
\text { Celery 3/ } \\
\text { Celery } \\
\text { Celery } \\
\text { Corn, sweet, husked 2// } \\
\text { Com, sweet, husked } \frac{4}{4} \\
\text { Com, sweet, unhusked } \\
\text { Ieeks } \\
\text { Mushrooms } \\
\text { Mushrooms } \\
\text { Mushrooms } \\
\text { Mishrooms } \\
\text { Mushrooms } \\
\text { Mushrooms }\end{array}$ & $\begin{array}{l}\text { Crate } \\
\text { Bunch } \\
\text { Hamper } \\
\text { Hamper } \\
\text { Cellophane bag } \\
\text { Wirebound crate } \\
\text { Crate } \\
\text { Crate } \\
\text { Crate } \\
\text { Cellophane bag } \\
\text { Celiophane bag } \\
\text { Crate } \\
\text { Crate } \\
\text { Cellophane tray } \\
\text { Cellophane tray } \\
\text { Crate } \\
\text { Wirebound crate } \\
\text { Basket (9 Ib.) } \\
\text { Basket (9 Ib。) } \\
\text { Basket (9 Ib.) } \\
\text { Carton (3 Ib。) } \\
\text { Prepackaged 5/, } \\
\text { Prepackaged b/ }\end{array}$ & $\begin{array}{l}16 \\
10 \\
20 \\
12 \\
14 \\
20 \\
13 \\
20 \\
23 \\
20 \\
20 \\
13 \\
13 \\
10 \\
10 \\
20 \\
20 \\
20 \\
16 \\
15 \\
15 \\
15 \\
15\end{array}$ & $\begin{array}{l}66 \\
64 \\
80 \\
69 \\
70 \\
65 \\
67 \\
76 \\
62 \\
68 \\
66 \\
70 \\
77 \\
59 \\
75 \\
83 \\
68 \\
67 \\
66 \\
70 \\
69 \\
68 \\
70\end{array}$ & $\begin{array}{l}50 \\
36 \\
60 \\
45 \\
43 \\
45 \\
44 \\
44 \\
46 \\
42 \\
47 \\
47 \\
53 \\
36 \\
39 \\
43 \\
36-40 \\
39 \\
35 \\
45 \\
46 \\
43 \\
45\end{array}$ \\
\hline
\end{tabular}

\section{I/ See footnote I, table I.}

2) Vacuum was drawn with experimental equipment to $3.3 \mathrm{~mm}$ mercury (measured with a McLeod gage) at which point water boils at $25^{\circ} \mathrm{F}$. Ice formed on spears of asparagus, but none on sweet corn.

\section{3) Data from Barger (I.)。}

4/ Vacuum was draw to $3.8 \mathrm{~mm}$. mercury.

5) Six pints packed in a cellophane-overwrapped wooden basket in a master carton. 6) One pound cellophane ovezwrapped, perforated tray。 
Table 3.miffectiveness of vacummoooling some vegetables and fruits with small surface area-tomvolume ratio

\begin{tabular}{|c|c|c|c|c|}
\hline Comnodity I/ & Containes & $\begin{array}{c}\text { Duration } \\
\text { of } \\
\text { vacuum } \\
\text { cycle }\end{array}$ & $\begin{array}{l}\text { Temperature } \\
\text { Beginn'ng } \\
\text { of cycle }\end{array}$ & $\begin{array}{r}\text { of commodity at- } \\
\text { End of } \\
\text { cycle }\end{array}$ \\
\hline & & Minutes & F。 & F。 \\
\hline AppIes, Golden Delicious & None & 45 & 79 & 50 \\
\hline Carrot, roots 2/ & Crate & 20 & 66 & 60 \\
\hline Cranberries 3 & $\begin{array}{l}\text { Cellophane bags } \\
\text { and trays }\end{array}$ & 14 & 74 & 68 \\
\hline Cucumbers & Baskets & 20 & 78 & 73 \\
\hline Grapes, Ribier 4/ & None & 20 & 69 & 63 \\
\hline Grapes, seedless & None & 20 & 70 & 64 \\
\hline Grapes, seedless & Lug & 20 & 64 & $40-45$ \\
\hline Grapes, Emperor & Lug & 15 & 63 & 50 \\
\hline Oranges & None & 10 & 75 & 72 \\
\hline Peppers, beII & Hamper & 20 & 80 & 50 \\
\hline Potatoes, intact 5/ & None & 30 & 65 & 57 \\
\hline Potatoes, skinnea 5/ & None & 30 & 65 & 45 \\
\hline Strawberries $4 /$ & None & 20 & 65 & 53 \\
\hline Strawberries, dry & Cup & 13 & 64 & 51 \\
\hline Strawberries, wet & Cup & 13 & 65 & 38 \\
\hline Toma toes & Cellophane tray & 10 & 73 & 67 \\
\hline Tomatoes & Cellophane tray & 20 & 77 & 71 \\
\hline
\end{tabular}

I/ See footnote I, tabie I.

2) The tops attached to these roots were cooled simultaneously to $38^{\circ} \mathrm{F}$.

3/ Unpublished data by H.W. Hruschka and Jo Kaufman, 1954.

4/ Data from Barger (I).

5) Data from Dewey ( 6 ). 
Table 4.--Temperature changes in vacuumwcooled wet and dry fruits and vegetables

\begin{tabular}{|c|c|c|c|c|c|c|c|c|c|c|}
\hline \multirow{6}{*}{ Commodity } & : & \multirow{6}{*}{ Container } & \multirow{6}{*}{\multicolumn{2}{|c|}{$\begin{array}{l}=\text { Iuration } \\
=\text { of } \\
\text { vacuum } \\
\text { cycie }\end{array}$}} & \multicolumn{3}{|c|}{ Wèt } & \multicolumn{2}{|c|}{$\mathrm{D}=\mathrm{y}$} & \\
\hline & $\approx$ & & & & \multirow{2}{*}{\multicolumn{2}{|c|}{$\begin{array}{l}\text { : Temperature of } \\
\text { : commodity at, }\end{array}$}} & \multirow{2}{*}{$\begin{array}{l}\text { :Drop } \\
: \text { in }\end{array}$} & \multicolumn{2}{|c|}{ :Temperature of } & \\
\hline & $:$ & & & & & & & :commodity & ato & $\begin{array}{l}\text { :Drop } \\
\text { a in }\end{array}$ \\
\hline & $\approx$ & & & & : $\overline{\text { Beginning }}$ & End of & $\bar{f}: t e m=$ & Beginning & End of & fatema \\
\hline & : & & & & :of cycle & cycle & :pera & :of cycle & cycle & :pera \\
\hline & $=$ & & & & $:$ & & :ture & $:$ & & :ture \\
\hline & & & & Miriutes & F。 & ${ }^{\circ}$. & 完. & ${ }^{\circ} \bar{F}$. & ${ }^{\circ} \bar{F}$ 。 & ${ }^{\circ} \mathrm{F}$ \\
\hline Celery & & Srate & & 12 & 54 & 38 & 16 & 52 & 41 & 11 \\
\hline Celery & & Crate & & I4 & 62 & 44 & 18 & 56 & 44 & 12 \\
\hline Cranberrie & & $\begin{array}{l}\text { Cellophan } \\
\text { bag or tr }\end{array}$ & & 19 & 71 & 64 & 7 & 72 & 68 & 4 \\
\hline Grapes & & Iug & & 15 & 64 & 51 & 13 & 64 & 51 & 13 \\
\hline Mushrooms & & Basket & & 17 & 70 & 43 & 27 & 70 & 45 & 25 \\
\hline Strawberri & & Cup & & 13 & 65 & 38 & 27 & 64 & 51 & 13 \\
\hline
\end{tabular}

I) Unpublished data from Hruschka and Kaufmaz, 1954. 
Table 5, wowffect of vacuum-cooling on weight losses of vegetables

\section{Minutes}

Celery I/

Cranberries 2/

Cellophane bag

Cellophane bag or tray

Cellophane bag

30

20

18

None

None

Cellophane bag

Cellophane bag

Cellophane bag

Cellophane bag

\section{Percent}

2.7

3/ 1.0

2.0

8

3.4

15

4.7

30

3.2

18

2.6

Soup $\operatorname{mix}$ I/

Spinach I/

If Data from Barger (I)。

2) Data from Hruschka and Kaufman 1954。

3/ Cranberries cooled only 6 degrees.

4/ Data from Friedman (9)。

5) Dáta from Dewey (5)。 


\section{LITERATURE CITED}

(1) Barger, W。 R。

1949. Further tests with vacuum orecooling on fruits and vegetables,

Salinas, Calif。, August 1949. U. So Bur. Plant Indus.,

Soils, \& Agr. Engin. Handings iransportation, \& Storage

Off. Rept。244。

(2) Burkhart, I.

1953. Vacuum cooling Arizona 1ettuce. West. Grower \& Shipper 24!(4): $20-22$.

(3) Clements, Jo

1949. Report on vacuun cooling of lettuce, Salinas, Galife, June 13-15,

U. S. Bur. Plant Indus., Soils, \& Agr. Engin. Handling;

Transportation \& Siorage Off. Rpt. 243.

(4) Cramer, F.

1954. Vacuum cooling. Market Growers Jour., Dec., p. 37.

(5) Dewey, D. H。

1950. Air blast and vacuum cooling of lettuce temperature and moisture changes. Amer. Soc. Hort. Sc:. Proc. 56: 320-326.

(6)

1952. Evaporative cooling of fruits and vegetables. Refrig. Engin. $60(12): 1281-1283,1295$.

(7) Friedman, B. A.

1949. Preliminary observations on vacuum cooling of fruits and regetables. U. S. Bui, Plant Indis, So:Is, and Agr。 Engiios Handing, Transportiotion \& Storage Off. Rpt. 245.

(8)

19L9. Vacuum cooling of fresh vegetables. Pre Packmage 3(3): 28 m.

(9)

1951. Vacum cooling of prepackaged spinach, coleslaw, and mized salead. Amer.Soc. Hort. Sci. Proc。 $58: 279-287$.

(10)

1952. Vacuur cooling of vegetables and fruits. Pre-PackoAge 5(12): $18-20,22,25$ 。

(17)

195 H. Brown spot complex of head Iettuce on easterm markets. Piant Dis. Rptr. $38(22): 847-851$. 
(12) Friedman, B. A. and Kaufman, Jo

1953. Comparison of the storage life of vacuum-cooled and ice-packed lettuce. U. S。 Bur. Plant Indus, Soils, \& Agr。 Engin., Handing, Transportation, \& Storage Off.Rpt. 309.

(13) Fuller, $H_{0} C_{0}$

1954. First carloads of lettuce handled by new method. The Packer, Nov。 6, p. 50。

(14) Hayes, $\mathrm{H}_{0} \mathrm{P}$.

1954. Vacuum cooling of produce. Refrig。 Engin, 62: 47-49, 90 .

(I5) Hodgman, C. D.

1949. Hendbook of Chemistry and Physics. Ed。31, Cf。p.1852-1853, Chem。 Rubber Pub. Coo, Cleveland, Ohio。

(16) Kasser, $M_{0}$

1944. Method and apparatus for treating perishable articles. U.S. Patent Off., No. 2, 344, $151, p_{0} 6$.

(17) Mazzola, I. C.

1946. "Flash freezing" of foods. Food Indus. 18(12): 73-77, 210, 212.

(18) Miller, I. C.

1952. Vacuum cooling saves costly process time. Food Engin., Oct,, p. IOL-III. 


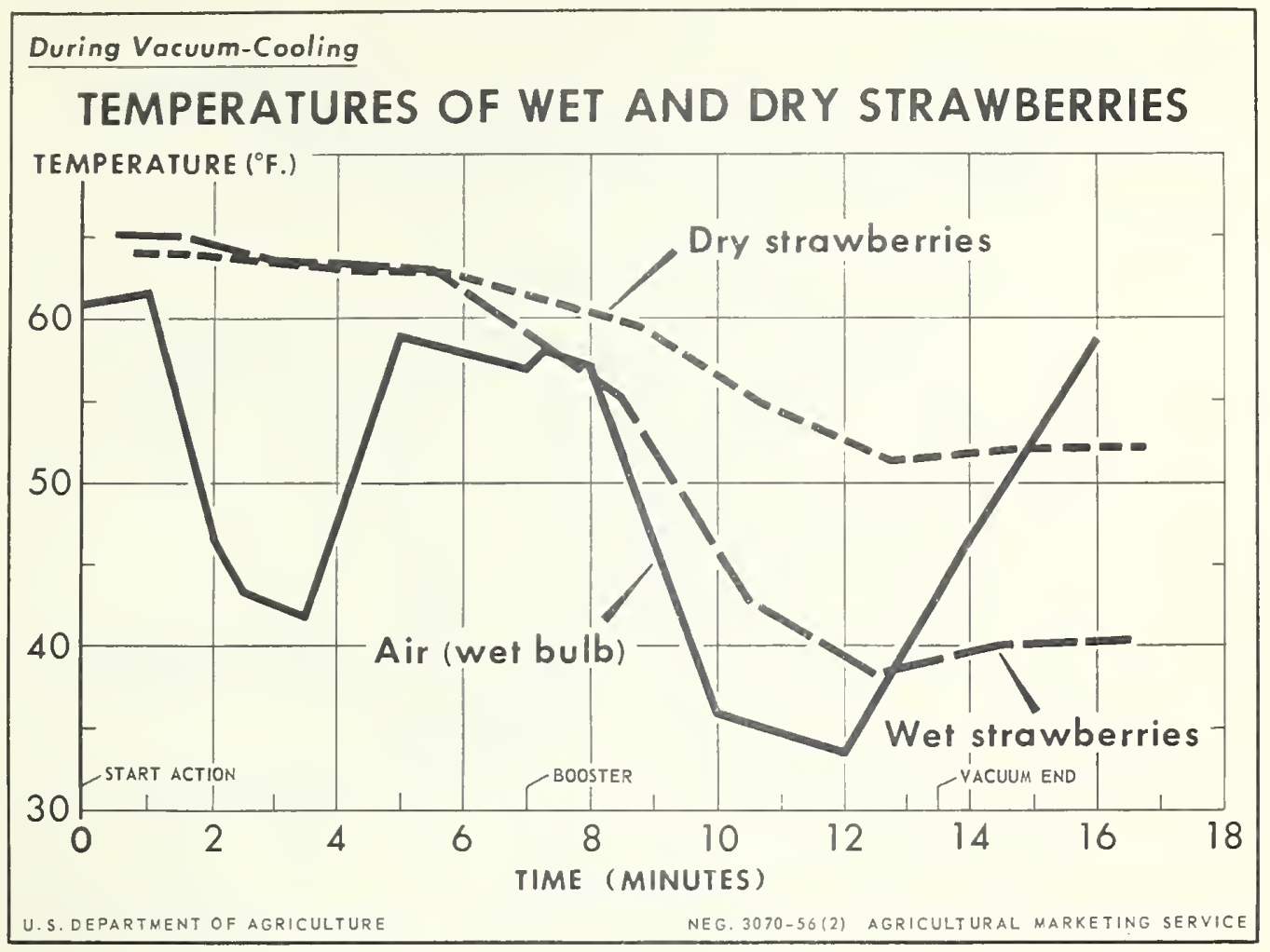

Figure 1

\section{During Vacuum-Cooling}

TEMPERATURE OF LETTUCE AND OF AIR

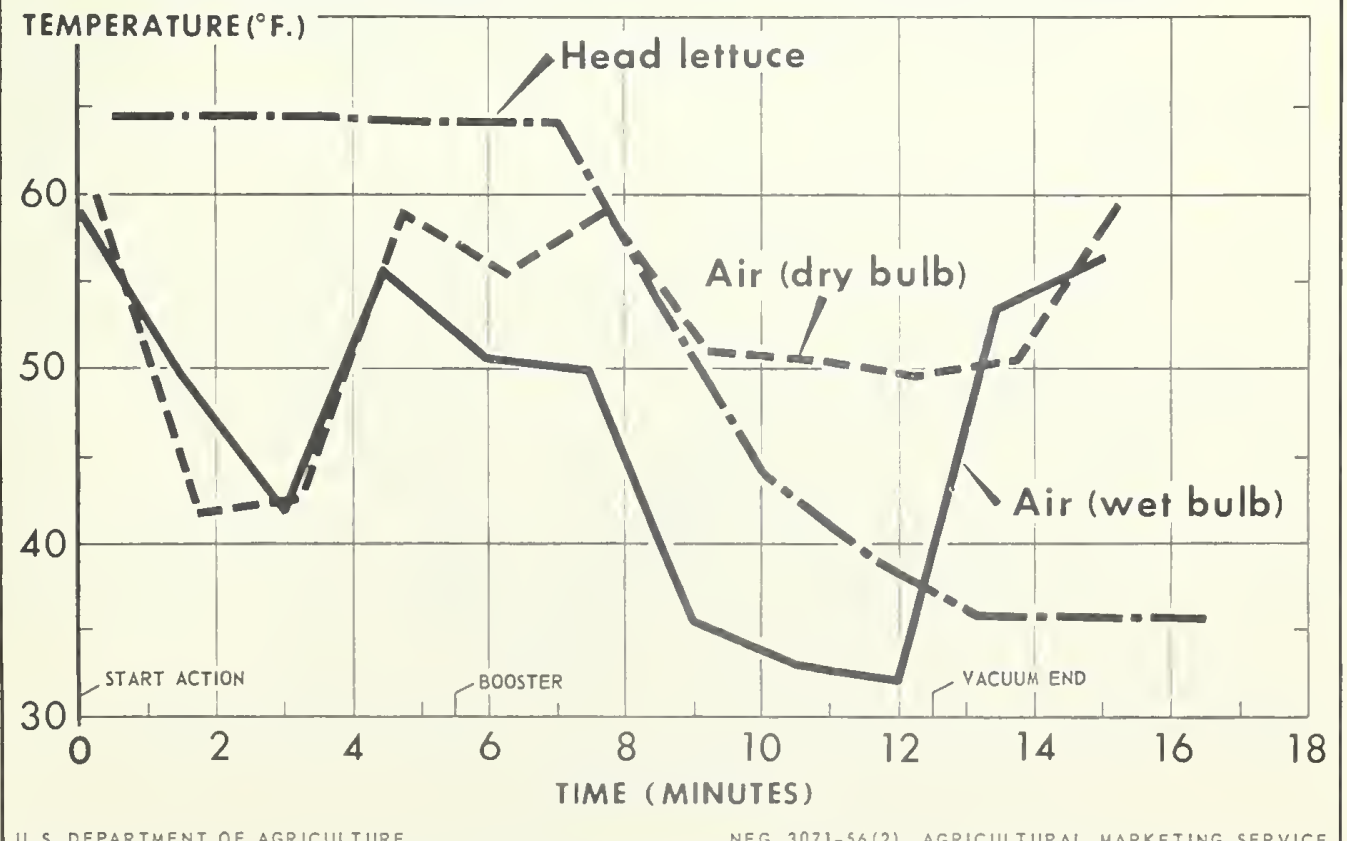




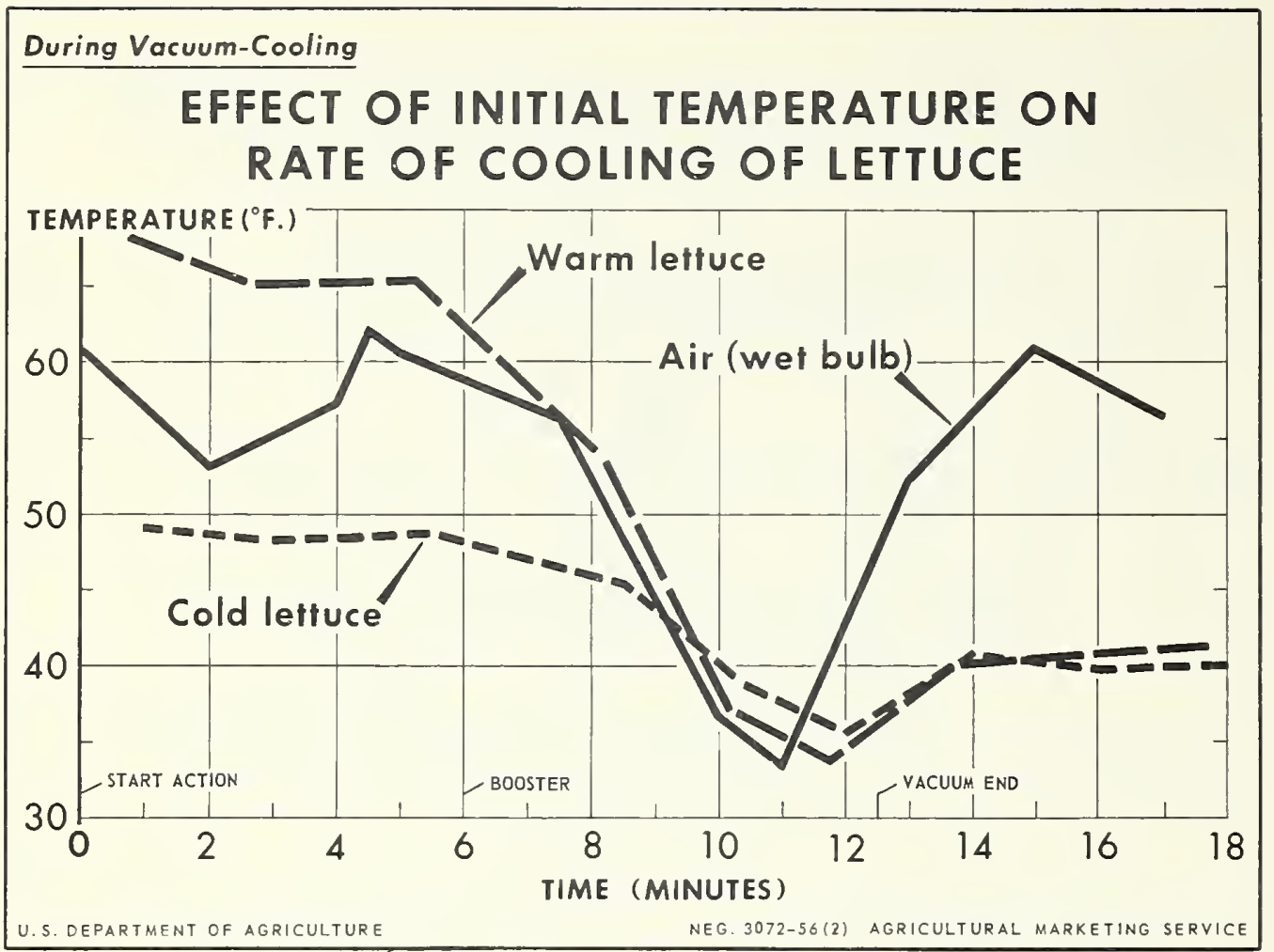

Figure 3

\section{During Vacuum-Cooling \\ EFFECT OF INITIAL TEMPERATURE ON RATE OF COOLING OF CELERY}

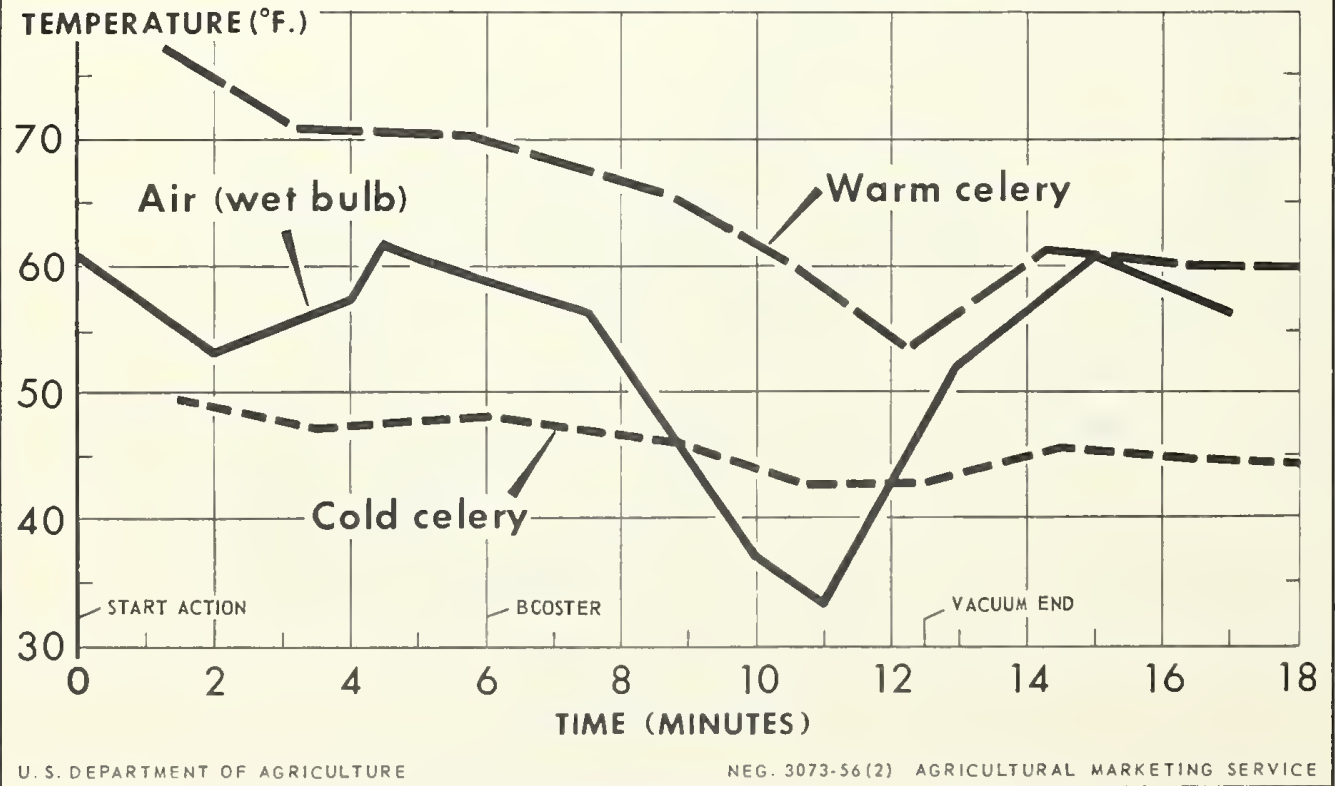




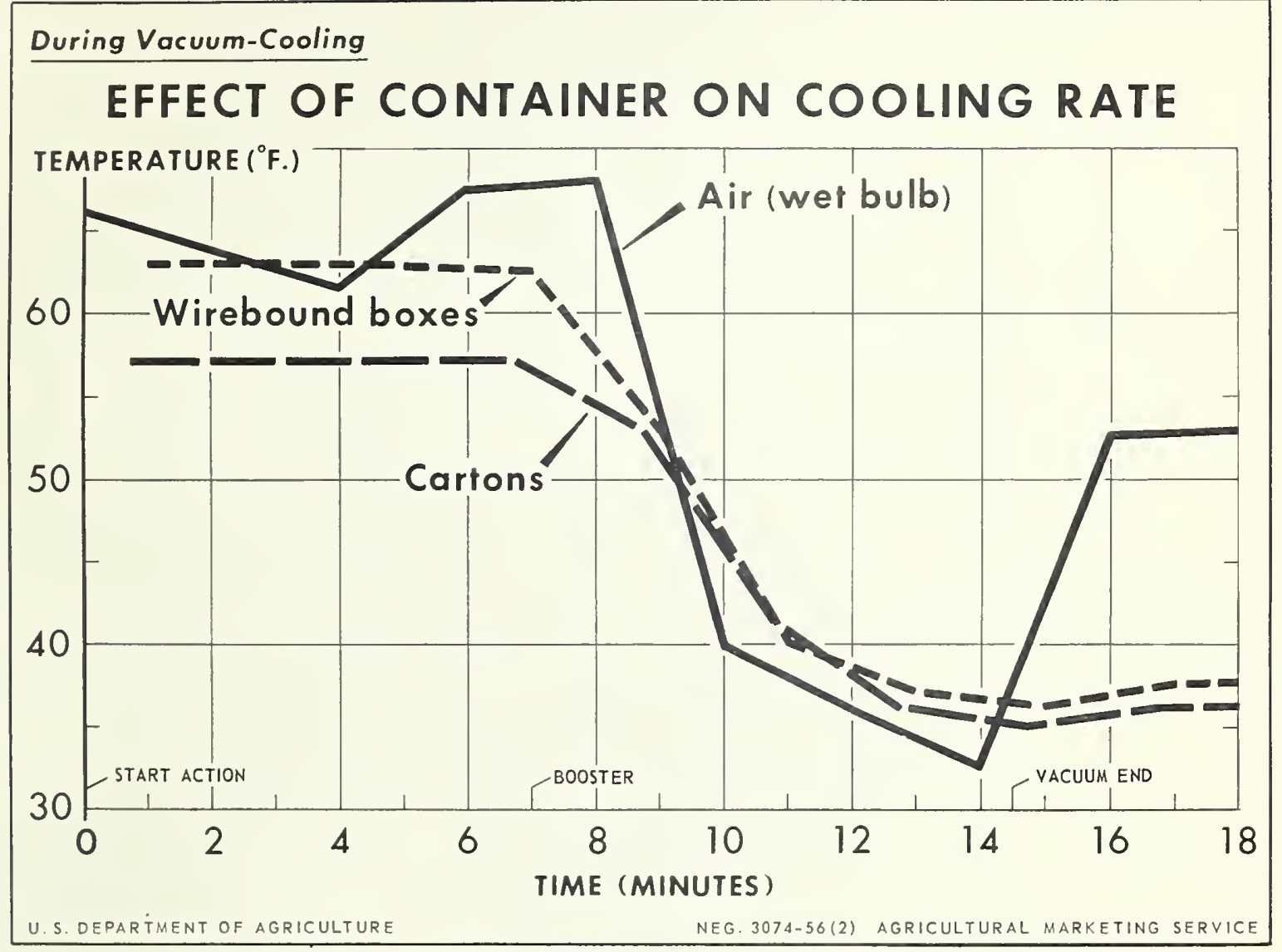

Figure 5 
